\title{
Conflitos entre democracia parlamentar e religião reacionária na Câmara Municipal de Fortaleza
}

\section{Conflicts between parliamentary democracy and reactionary religion in the City Council of Fortaleza}

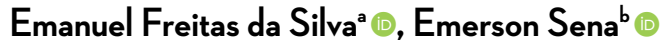

Resumo O objetivo desse artigo é analisar as dinâmicas da representação política moldada por elementos de pertença religiosa. Para tanto, toma-se como corpus de análise as enunciações (discursos, postagens e imagens compartilhadas em redes sociais) encenadas por dois vereadores da cidade de Fortaleza durante a tramitação de um projeto de lei que versava sobre a liberdade de cátedra, entre outubro e novembro de 2019. Partindo de metodologias qualitativas combinadas às noções de campo e discurso políticos, com a análise de imagens compartilhadas em redes sociais, escolhidas como paradigmáticas pela carga semântica da ideia de "guerra ao inimigo", pretendemos compreender como se engendrou, e se reforçou, o que consideramos como um pacto "político-religioso" entre os dois vereadores e o conjunto de seus seguidores, transformando-os, no exercício do mandato parlamentar, de políticos em "representantes da fé"; seus eleitores em "adeptos da fé"; e seus opositores em "inimigos da fé". Assim, a leitura do texto possibilitará compreender uma das facetas mais importantes do conservadorismo político brasileiro contemporâneo: a legitimação do campo religioso cristão e a legitimação política a partir desse campo.

Palavras-chave Discurso político. Pacto político-religioso. Representação.

Abstract The purpose of this article is to analyze the dynamics of political representation shaped by elements of religious belonging. To this end, the corpus of analysis uses the statements (speeches, posts and images shared on social networks) staged by two city councilors in the city of Fortaleza during the processing of a bill that dealt with the freedom of the chair, between October and November 2019. Starting from qualitative methodologies combined with notions of political field and discourse, with the analysis of images shared on social networks, chosen as paradigmatic by

a Doutor em Sociologia. Professor do Curso de Ciências Sociais e dos Programas de Pós-Graduação em Sociologia e em Planejamento e Políticas Públicas (UECE). Pesquisador do LEPEM-UFC (Laboratório de pesquisas em processos eleitorais e mídia), onde desenvolve pesquisa sobre política e religião. E-mail: emanuel.freitas@uece.br

b Doutor em Ciência da Religião, antropólogo, Professor do Departamento e do Programa de Pós-Graduação em Ciência da Religião da Universidade Federal de Juiz de Fora, MG, Brasil. E-mail: emerson.pesquisa@gmail.com 
the semantic load of the idea of "war on the enemy", we intend to understand how it engendered, and if reinforced what we consider to be a "political-religious" pact between the two councilors and the group of their followers, transforming them, in the exercise of parliamentary mandate, from politicians to "representatives of the faith"; its voters into "adherents of the faith"; and its opponents in "enemies of the faith". Thus, reading the text will make it possible to understand one of the most important facets of contemporary Brazilian political conservatism: the legitimation of the Christian religious field and the political legitimation from that field.

Keywords Political speech. Political-religious pact. Representation.

\section{INTRODUÇÃO}

O objetivo deste artigo é apresentar as modalidades da representação política religiosa tomando como corpus de análise discursos em plenário, postagens em redes sociais e imagens compartilhadas por dois vereadores da cidade de Fortaleza durante a tramitação de um projeto de lei que versava sobre a liberdade de cátedra, entre outubro e novembro de 2019: a vereadora evangélica Priscila Costa e o vereador católico-carismático Jorge Pinheiro. Tomaremos ambos os políticos como o esboço de um tipo ideal de duas forças político-religiosas cristãs que têm se congregado em torno da pauta conservadora-reacionária. Acreditamos que estudos de casos como este podem ajudar a entender as engrenagens da máquina de guerra identitário-religiosa-reacionária e o sistema representativo-liberal, defendido como arena de acomodação de conflitos e valores distintos.

Lastreado em metodologias qualitativas que trabalham com paradigmas indiciários, trazemos alguns discursos proferidos pelos dois vereadores, suas tomadas de posição durante a tramitação do projeto e imagens compartilhadas em suas redes sociais para compreendermos como se engendrou, e se reforçou, um pacto "político-religioso", transformando-os, no exercício do mandato, de políticos em "representantes da fé"; seus eleitores em "adeptos da fé"; e seus opositores em "inimigos da fé", por meio de coleta dos dados e informações nos anos de 2019 e 2020. A atuação foi recortada a partir da ideia de guerra ao inimigo, que caracteriza boa parte dos grupos cristãos hegemônicos no Brasil e que, por isso, coloca em xeque o parlamento como lugar dos dissensos e da repactuação democrática contínua (Amossy, 2017; 2018). Acionando a gramática religiosa para a exposição de seus argumentos frente aos embates em torno do projeto, ambos os vereadores produziram um trabalho parlamentar que teve dois efeitos: a autolegitimação como representantes fiéis da cosmovisão cristã e a nomeação do autor do projeto, 
vereador Evaldo Costa (Partido Comunista do Brasil), e da esquerda em geral, como "inimigos da fé cristã".

\section{1 - AS RELAÇ̃̃ES ENTRE RELIGIÃO E POLÍTICA NO BRASIL CONTEMPORÂNEO}

Aspecto importante da compreensão das dinâmicas da representação política no Brasil contemporâneo é a presença de atores do campo religioso que, cada vez mais, elegem-se a diversos cargos políticos, sobretudo no Poder Legislativo, e exercem seus mandatos a partir de uma lógica de defesa dos interesses das instituições religiosas a que estão filiados, fazendo de tal defesa a razão de ser de seus mandatos.

Parte considerável das igrejas evangélicas e do movimento carismático católico saiu de uma atuação minoritária, pouco articulada, para uma atuação mais global, articulada, majoritária, cada vez mais reacionária. Ao invocarem o direito à diferença, esses grupos lançam nas arenas públicas e políticas uma operação de guerra que só pode ser efetivada por um tipo de linguagem religiosa (maniqueísta) combinada com uma dupla tática: quando são criticados e são objetos de manobras políticas contrárias previstas no jogo da democracia representativa, se dizem "perseguidos" e "verdadeira minoria”; quando avançam contra setores não-religiosos laicos dos mais variados matizes ideológico-políticos e atores religiosos cristãos não-alinhados aos ideais reacionários-moralistas, vestem uma armadura tripla: linguagem religiosa bélica, linguagem performático-teatral impermeável à racionalidade iluminista-igualitária moderna e uma linguagem de maioria ("somos representantes da maioria do povo brasileiro, cristão e conservador”) (SILvEIRA, 2008a; 2008b).

No caso do Brasil, interessa ponderar que o que aqui nomeamos de interesses aos quais tais parlamentares afirmam ser o pilar de seus mandatos não está estreitamente relacionado a uma instituição religiosa em si, mas a uma realidade mais ampla, a uma agenda cristã, que se notabiliza por atacar políticas públicas, sobretudo no campo dos costumes, que dizem ser afronta aos ideais da família cristã, e algo ao qual precisam fazer frente pois buscam impor-se totalitariamente em contraposição ao interesse de tal maioria.

Sabendo-se que a religião se encontra fora de seus tradicionais espaços (templos) e, na contemporaneidade, adentra espaços sociais laicos e republicanos (sendo a política um deles), cumpre compreender o mecanismo pelo qual "ao perceber o campo político como uma arena sujeita às influências demoníacas", onde projetos de leis e políticas públicas estavam a ser postas em ação para corrigir distorções, "foi possível instaurar-se uma verdadeira cruzada no campo político" (TADvald, 2010, p. 84). Com esse movimento, fazem surgir uma "ação política 
regulada pelos 'planos de deus' expressos na bíblia” (CAmpos, 2010, p. 41), planos esses que são devidamente codificados pelos "representantes de deus na terra", os sacerdotes e pastores que dirigem as instituições religiosas e indicam-se a si mesmos ou a outros como os representantes do projeto divino no plano político. A política constituiu-se como um campo privilegiado de missão e ação religiosas, espaço por excelência da defesa de seus ideais.

O que podemos observar, a partir dessa atuação, é um processo de esgarçamento dos elos seculares que definem a política moderna ${ }^{1}$, tendo como consequência imediata a promoção de um grupo específico da sociedade civil de cunho religioso, autocentrado e monopolizador, enquadrando as ações estatais sob o molde do que seja "verdadeiramente cristão e moral", dando lugar a "práticas de construção identitária que evitam os diferentes", resultando daí o "estímulo a uma certa intolerância fundada na crítica constante do 'outro"” (MIRANDA, 2011, p.39), agora dentro da esfera pública, no espaço de decisões políticas que deveria ser o lócus da laicidade e da pluralidade. Vivenciamos, assim, um conservadorismo impregnado que tende a ler a estrutura social e a ação do Estado vinculadas aos valores religiosos cristãos, ganhando o cristianismo o status de religião privilegiada e com pleno direito de influenciar os rumos do país: "a Bíblia transformou-se na grande referência ética para pensar a sociedade e a política” (MIRANDA, 1999, p. 14).

Contudo, se têm sido recorrentes empreitadas políticas de lideranças religiosas cristãs do segmento evangélico, não se observavam tomadas de posições mais claras no jogo político por parte de lideranças da Renovação Carismática Católica (RCC), como se pôde observar a partir das eleições de $\mathbf{2 0 1 0}^{2}$, e ainda mais nas eleições de 2014 e de 2018, no que tange ao voto presidencial, sendo a RCC o segmento católico com maior crescimento de engajamento das disputas eleitorais nos anos 2010. Assim, vemos "uma reposição dos temas na agenda política da maioria dos grupos religiosos favorecendo as questões de cunho moral e privado" (MACHADO, 2015, p. $34)^{3}$, aumentando a atuação de políticos ligados às denominações evangélicas e, agora, favorecendo a empreitada de políticos ligados ao movimento carismático

1 O estudo de DIP (2018) sobre a "bancada evangélica” no Congresso Nacional pode ser visitado como um dos mais recentes sobre a temática.

2 Particularmente na militância em torno da questão do "aborto" e dos direitos das minorias. Sobre isso, ver Machado (2012) que, apesar de tratar da atuação de evangélicos, tal atuação se assemelha em muitos aspectos à atuação de lideranças e parlamentares católicos, sobretudo os ligados à RCC.

3 Embora estudos como os de Miranda (1999) e Machado (2006) tenham observado tal empreitada da RCC já nos anos 90, sustento aqui que a mudança, nos anos 2010, operou-se em relação a uma militância mais perceptível no que tange à disputa presidencial, e não nas disputas legislativas, como os estudos já apontavam. 
católico. Logo, a atuação deliberada de atores do campo religioso (evangélicos e carismáticos) na política eleitoral nos permite compreender o ativismo religioso conservador que, caucionado numa visão negativa da política brasileira, vai mobilizando-se na perspectiva de construção de uma nova cultura política no país, crente no "dever moral” de interferir na condução das políticas públicas.

\section{2 - A POLÍTICA COMO DISCURSO: BREVES CONSIDERAÇÕES}

O discurso político, proferido dentro do campo político e por atores nele envolvidos, pode ser compreendido como um "sistema de pensamento", que produz um ideal de referência para a produção de opiniões e posicionamentos, e como um "ato de comunicação" que objetiva produzir adesão e consentimento; e como um "comentário", que se estabelece em relação a um conjunto de fenômenos que circulam no espaço social (CHARAUdEAU, 2008b).

Compreender o discurso político ${ }^{4}$ como um texto dentro de um contexto é compreender as condições precisas em que ele é possível de produzir-se e circular, como ato linguístico-imagético, que atua, inclusive, na (re)construção de um mundo sobre o qual visa atuar. Como "contrato de comunicação", posiciona sujeitos a serem reconhecidos em diversas posições: produtores, receptores, antagonistas etc.

A noção de contrato pressupõe que os indivíduos pertencentes a um mesmo corpo de práticas sociais estejam suscetíveis a chegar a um acordo sobre as representações linguageiras dessas práticas sociais. [...] Nessa perspectiva, o ato de linguagem torna-se uma proposição que o EU faz ao TU e da qual ele espera uma contrapartida de conveniência (CHARAUdEAU, 2008a, p. 56).

A partir da citação acima, compreende-se que o discurso político é algo a ser compreendido no plano do "relacional": quem fala, como fala, a quem fala, de onde fala. É uma interação entre partes a partir de um lócus. Ao que nos parece, a condição para o contrato de enunciação, o próprio fazer discursivo, dos dois parlamentares era exatamente a apresentação de si como sujeitos do campo religioso, e tal apresentação dá-se elencando elementos de tal campo, produzindo efeitos ao mesmo tempo de fidelidade política aos dois, que demonstravam ter fidelidade religiosa, o que os fazia legítimos.

4 “O discurso político não esgota, de forma alguma, todo o conceito político, mas não há política sem discurso. Este é constitutivo daquela. A linguagem é o que motiva a ação, a orienta e lhe dá sentido [...] A ação política e o discurso político estão indissociavelmente ligados, o que justifica pelo mesmo raciocínio o estudo político pelo discurso" (CHARAUDEAU, 2008b, p.39). 
Ora, a política é um “espaço de persuasão” (ChARAUdEAU, 2008b, p. 19) no qual os atores movimentam-se com argumentos da razão e da emoção, movendo-se por um debate entre "uma verdade do dizer e uma verdade do fazer" (p.23), que não seria possível sem a mediação dos meios de comunicação (em nossos dias, das redes sociais), dispositivos que produzem uma ideia de proximidade representativa que outros meios não podiam proporcionar.

Exercendo-se como convencimento é que o discurso político opera como um ato de idealidade, na medida em que enuncia aos interlocutores uma esperança social a partir daquilo que se diz e por meio de quem se diz ${ }^{5}$. Na relação de embate com outros discursos (textos ou imagens), o discurso político intenta conquistar um poder que é, sobretudo, um poder de enunciar (palavra) uma promessa, seja de mudança na ordem das coisas, seja de sua continuidade. Ideias são encenadas na cena pública aos moldes de uma dramaturgia acerca do mundo social; daí a importância da compreensão do contexto em que um discurso é produzido para se compreender os movimentos do campo político. Feitas estas breves considerações, no tópico seguinte continuaremos a discutir, já na análise do material empírico, questões pertinentes a este referencial teórico.

\section{3 - CÂMARA MUNICIPAL DE FORTALEZA: A ARENA DE UMA BATALHA ESPIRITUAL}

Nosso corpus de análise trata-se de um conjunto de imagens produzidas nas redes sociais de dois parlamentares que travaram acirrada disputa contra um projeto de lei, apresentado na Câmara Municipal de Fortaleza, em outubro de 2019, que versava sobre liberdade de cátedra para professores. Em nossa compreensão, a mobilização, e as imagens postadas objetivavam produzir com os seguidores das redes (que foram ou não eleitores) uma espécie de pacto político-religioso.

Utilizamos essa expressão por entendermos que era objetivo dos vereadores mostrarem-se performaticamente fiéis a um conjunto de crenças daqueles que lhes seguiam nas redes sociais, autolegitimando-se. Para alcançarem tal intento, encenaram uma disputa a partir da semântica religiosa, sem deixar de postarem-se como parlamentares vigilantes no parlamento e como atores do campo político. Selavam, com essa duplicidade, uma relação de proximidade e confiança entre aqueles que acompanhavam o seu trabalho, e sua vivência religiosa, no espaço das redes sociais.

5 O poder político, como lembra Bourdieu (2012), faz crer e faz ver. 


\section{1 - O PERFIL DOS PARLAMENTARES}

Priscila Costa, jornalista, foi eleita para seu primeiro mandato como vereadora, na cidade de Fortaleza, em 2016, com 5.491 votos, pelo Partido Renovador Trabalhista Brasileiro (PRTB). É filha e neta de pastor protestante da Assembleia de Deus, mãe de três filhos. Atualmente, porém, está filiada ao Partido Social Cristão (PSC). Em 2018, ainda pelo PRTB, disputou uma vaga para a Câmara Federal, obtendo um total significativo de 48.041 votos, quase oito vezes a mais do que o total obtido dois anos antes, somente na cidade de Fortaleza. Em seu Instagram6 apresenta-se como "vereadora de Fortaleza, conservadora, jornalista, militante da causa Pró-Vida e apaixonada pelo Evangelho de Cristo".

Durante o ano de 2019, foi desenvolvida uma pesquisa de mestrado sobre representação religiosa na Câmara Municipal de Fortaleza, tomando como caso de análise os mandatos dos dois parlamentares aqui considerados. Trazemos a seguir, com a devida autorização do autor da pesquisa ${ }^{7}$, algumas declarações de ambos que nos podem fazer compreender os elementos constituintes da representação política de atores do campo religioso segundo suas próprias enunciações.

Percebendo a crescente religiosidade do povo brasileiro como algo "benéfico", pois isso se deveria "aos resultados práticos alcançados nas vidas individuais das pessoas", a vereadora pondera que a igreja "precisa repensar sua influência" (na vida social), "ultrapassar as quatro paredes da igreja e avançar, influenciar outras esferas da sociedade”. Segundo ela:

A Igreja ainda não é tão efetiva na transformação da sociedade. Acredito que isso acontece devido ao fato que ainda não nos despertamos para nosso real papel social. De acordo com minha fé, acredito que Deus criou todas as coisas e nos orienta a governar todas as coisas: a cultura, as artes, a educação, o esporte etc. Tudo isso é assunto da igreja, pois a igreja não é uma instituição, a igreja somos nós, e nós devemos influenciar. Creio que essa mentalidade foi perdida, vivemos muito no institucional. Temos que pensar nossa atuação de forma mais ampla, por exemplo, como promotor de justiça, como posso influenciar como cristão na promotoria? Na empresa? [...]. Portanto, aqui, onde desempenho minha função social, para o pensamento errôneo, não precisaria fazer nada em nível de minha fé. Não é isso que deve acontecer! Somos igreja e devemos desenvolver nossa fé em todos os lugares (FREITAS, 2020, p. 167, grifos colocados).

6 Disponível em www.instagram.com/priscilacosta. Acesso em 31 de maio de 2021.

7 Trata-se da pesquisa de Marcelo Freitas (2020). 
Para a vereadora, haveria um espaço dedicado à igreja para operar a "transformação da sociedade", uma vez que tal feito seria destinado à igreja "por Deus"; cultura, artes, educação: tudo estaria sob o escrutínio dos "crentes", cabendo a estes "influenciar" essas dimensões da vida social, indo além dos limites eclesiais. Para ela, o lugar de exercício da fé não se resume à igreja, expandindo-se por todo o espaço social, numa ação de verdadeira captura/contaminação da vida social à (sua) religião.

Reside, pois, na incompreensão das devidas distinções entre o campo da política e o campo da religião, sobretudo entre os fundamentalistas (que veem na política um instrumento a serviço de sua crença), vendo aquela como espaço de defesa desta, a percepção da vereadora de que as contaminações entre os dois campos (religião e política) não ofereça dissonância:

Não vejo nenhum problema na relação entre política e religião, inclusive, entendo ser muito legítima essa relação, pois a política existe para que a visão de mundo de determinados grupos seja representada, daí nossa visão de mundo é completamente formada dentro da religião. Eu poderia dizer que nossa visão de mundo é formada pela cultura, porém digo religião, pois a própria cultura é estabelecida pelos fundamentos de fé vivenciada por dada sociedade, por exemplo, quando falamos de uma mentalidade ocidental, estamos falando de uma mentalidade criada da tradição judaico-cristã. Então nossa fé marca nossa cultura e a política acaba existindo para representar isso, ou seja, o que o povo é, pensa. A religião é parte disso (FreITAS, 2020, p. 179, grifos colocados).

Observe o leitor o que foi dito acima: a razão de ser da política é a representação de determinados grupos, dos quais se destaca a religião. No caso, a que ela considera como a "maioria". A política seria o meio mais eficaz para que o conjunto de crenças e valores da (suposta) maioria se perpetue ${ }^{8}$, como "nossa marca" ou como "aquilo que o povo é".

Jorge Pinheiro, advogado, elegeu-se para seu primeiro mandato como vereador, também em 2016, pelo Partido da Social Democracia Cristã (PSDC), com um total de 5.969 votos. Havia sido candidato, pelo mesmo partido, em 2012 (quando

8 “As sociedades mais plurais estão no ocidente, são sociedades onde prevalece a fé cristã. Então, um representante cristão já representa a experiência mais plural que a humanidade já experimentou. Como parlamentar cristã em uma sociedade de mais de $80 \%$ de cristãos, não seria legítima como representante da cidade?”, questiona ela em outro momento. 
alcançou 2.076 votos), mas não havia logrado êxito ${ }^{9}$. É membro consagrado da Comunidade Católica Shalom, na modalidade Comunidade de Aliança, há 26 anos, tendo já sido enviado em missão para a cidade de Salvador. Em seu Instagram ${ }^{10}$, apresenta-se como "consagrado na Comunidade Católica Shalom, casado, pai de 7 filhos, advogado, pró-vida, conservador e vereador de Fortaleza”.

Advogado com atuação em Execução Penal e Direito Canônico, é membro da Sociedade Brasileira de Canonistas. Foi assessor jurídico da Direção das Casas de Custódia (CPPL-I e CPPL-III) da Secretaria de Justiça e Cidadania do Ceará (20102015). É apresentador do Programa "Relacionamentos de A a Z”, transmitido pela Rádio Shalom AM 690, aos sábados, das 13h às 15h, com informações e entrevistas voltadas, principalmente, para "preparação adequada para constituição da família”, sua "preservação" e dicas para uma boa vivência e "superação de crises familiares".

Assim como Priscila, Jorge também recorre à ideia de "chamado" para legitimar seu ingresso na vida pública, fruto de uma oração, escolha do próprio deus. Segundo ele:

Na verdade, o "click" mesmo foi um dia que disse que tinha certeza que Deus não queria que eu participasse da política, foi nessa hora que senti um negócio dentro de mim, Deus dizendo "Eu nunca disse isso para você". Eu respondi: "Tu não me disseste isso, Deus! Então é coisa de minha cabeça?” Foi daí que comecei a acreditar que Deus poderia querer que entrasse na vida política. Passei a meditar e a rezar mais sobre isso. Daí foi me encaminhando até me candidatar pela primeira vez (FrEITAS, 2020, p. 165, destaques nossos).

Jorge se diz representantes daqueles "que acreditam que os valores devem estar permeados na sociedade: família, vida"11 Por isso mesmo não vê problemas nas relações entre religião e política, “desde que a ação política não contradiga a

9 Miranda (2015) realizou uma interessante análise de sua candidatura, assim como de outros membros da RCC, naquela eleição. Por ocasião da entrevista, Jorge disse o seguinte, comparando o seu desempenho nas duas eleições: "O que mudou de uma campanha para outra é que na segunda, um conjunto de fatores me favoreceram. Por exemplo, dentro da Comunidade não houve nenhum outro candidato. A minha comunidade de fé não diz: "fulano é o candidato, é nosso candidato". Você nunca vai ouvir o fundador da Comunidade dizendo em quem vai votar. Ele não diz para ninguém, nem para deputado estadual ou federal, presidente, vereador”. Na verdade, o fato de a Comunidade ter lançado apenas seu nome, e não 4 como em 2012, foi crucial para sua vitória, o que confere ao analista a hipótese de que o lançamento único de candidatura deixa margem, mais do que suficientes, para que a Comunidade diga, sim em quem votar.

10 Disponível em: instagran.com/jorgepinheiro

11 Sem dúvida alguma, é a este grupo que o vereador crer representar, e ao qual pensa dever o seu mandato. Age, nesse sentido, movido por aquilo que melhor representa, em seu entender, os interesses do grupo. Sobre esse tipo de relação, própria do campo político, Bourdieu nos diz que "o homem político retira a sua força política da confiança que um grupo põe nele. Ele retira 
minha fé e a pureza de meu testemunho”. Durante a atual legislatura, dois projetos de lei de sua autoria ilustram o cenário de hegemonia cultural cristã nas votações, nos permitindo observar a identificação desses parlamentares com a "agenda conservadora", tida como "agenda cristã", no atual cenário político do país. O primeiro diz respeito a uma Moção de Repúdio à exposição Queer Museu: proposta por Jorge Pinheiro, votada no dia 21 de setembro de 2017 e aprovada por 22 dos 24 vereadores presentes. O segundo, seria uma Moção de Repúdio ao especial de Natal da Porta dos Fundos: também de autoria de Jorge Pinheiro, votada no dia 14 de dezembro de 2019, contou com voto favorável de 38 dos 39 presentes.

\section{2 - O PROJETO DE LEI E A ENCENAÇÃO DO PACTO POLÍTICO-RELIGIOSO}

No dia 12 de maio de 2019 a Câmara Municipal de Fortaleza começava a discutir o Projeto de Lei 524/2018, de autoria do deputado Evaldo Lima (PCdoB). Em matéria publicada no Jornal $O$ Povo, no dia seguinte, podia-se ler:

Enquanto no cenário nacional ganham destaque as discussões quanto ao movimento Escola Sem Partido - apoiado inclusive pelo presidente Jair Bolsonaro -, a Câmara Municipal de Fortaleza voltar a discutir esta semana, projeto de lei que caminha no sentido inverso. De autoria do vereador Evaldo Lima (PCdoB), a matéria pretende assegurar a liberdade de cátedra de professores, além de detalhar mecanismos de proteção em casos de violência no ambiente escola.

"A ideia fundamental (é que) os atores do ambiente educacional devem dispor, respeitados os limites constitucionais, de um ambiente escolar que permita liberdade de aprender, ensinar, pesquisar e divulgar o pensamento, a cultura, a arte, a ciência com pluralidade, com respeito e com tolerância”, explica Lima. O parlamentar relata que o projeto foi resultado do diálogo com professores e também com instâncias da educação, como a Secretaria de Educação do município.

O projeto de lei detalha o procedimento a ser seguido em casos de agressão verbal ou física a professores em ambiente escolar, inclusive estabelecendo prazos para a investigação do ocorrido e especificando as medidas para a proteção do educador. Além disso, também aponta garantia para livre manifestação dos professores, inclusive com a proibição de "fotografar, filmar ou gravar em áudio a

o seu poder propriamente mágico sobre o grupo da fé na representação que ele dá ao grupo e que é uma representação do próprio grupo e da sua relação com os outros grupos” (2002, p. 188). 
atuação do professor”, sem o consentimento deste - a prática tem se difundido pelo País, sendo, inclusive, incentivada por políticos ${ }^{12}$.

Entre maio e outubro, durante o longo período de tramitação, Jorge Pinheiro apresentou cinco emendas ao projeto. A primeira considerava como violência contra os alunos "o ensino e a promoção da ideologia de gênero nas escolas de Fortaleza"; a segunda retirava a proibição dos alunos filmarem os professores em sala de aula; a terceira assegurava ao aluno a obrigatoriedade de denunciar à direção da escola casos de eventuais agressões; e a quinta retirava da Secretaria de Educação o dever de punição pelas eventuais agressões sofridas pelo professor no exercício da profissão.

Como é possível ver, as emendas do vereador carismático destruíram a feição original do projeto, transformando-o numa versão daquilo que apregoavam os Projetos ligados ao Escola sem Partido, à época já declarados inconstitucionais pelo STF. Por conta disso, os vereadores favoráveis ao projeto, com o apoio do Sindicato dos Professores de Fortaleza, o SINDIUTE, iniciaram uma campanha de mobilização pela aprovação do mesmo, denunciando a armadilha preparada por Jorge Pinheiro que, ao inserir questões ligadas à "ideologia de gênero" no projeto, estaria ensaiando uma campanha de difamação (artificial) nas hostes conservadoras da cidade. De um projeto de lei que preconiza a proteção do exercício da atividade docente, o projeto se transformou num oportunismo do ensino do que chamam de "ideologia de gênero".

Durante o Pequeno Expediente do dia 03 de outubro de 2019, o vereador Evaldo Lima (PCdoB) apresentou o Projeto, de sua autoria, que versava sobre a liberdade de expressão do professor em ambiente escolar e proteção deste em caso de violência no âmbito da escola, no exercício da profissão. Inicialmente nomeado como "lei da liberdade de expressão", no decorrer da tramitação passou a ser chamado de "lei da liberdade de cátedra".

Caso o Projeto fosse aprovado, ficariam vedadas: "todas as formas de cerceamento de opiniões e manifestações por meio de agressões físicas ou verbais; todas as atitudes, individuais ou coletivas, que possam configurar prática de intolerância e todas as ações ou as manifestações passíveis de serem tipificadas como crimes de calúnia, injúria ou difamação”.

12 Disponível em: https://www.opovo.com.br/jornal/politica/2019/o5/12/camara-municipal-coloca-liberdade-de-catedra-em-discussao.html. Acesso em 13 de maio de 2020. 
Além disso, estariam proibidos: "o uso de equipamentos eletrônicos para fotografar, filmar ou gravar em áudio a atuação do professor em sala de aula, para fins de constrangimento ou violação de direitos, salvo em caso de boa-fé induvidosa e com a permissão do professor"13. Além disso, o projeto também definia os termos "liberdade de expressão" do professor.

Logo após o autor do projeto fazer sua apresentação, Priscila Costa iniciou o primeiro de seus discursos contrários. Em mais de 10 minutos de fala, criticou o projeto, os professores e aquilo que ela julgou ser uma "falsa campanha" contra o vereador Jorge.

Na reunião da Comissão de Constituição, Justiça e Legislação Participativa, da qual Jorge Pinheiro e Priscila Costa eram integrantes, realizada em 24 de outubro, foram levados à votação tanto o texto original, que recebera parecer favorável do relator, vereador Didi Mangueira, quanto as emendas que foram propostas, todas de autoria de Pinheiro. Além de ser favorável ao projeto, o relator também se manifestou desfavorável às emendas propostas, com destaque para a primeira, que visava proibir o ensino de "ideologia de gênero", alegando, o relator, a inconstitucionalidade da mesma por ferir, exatamente como o texto originário visava promover, a liberdade de expressão; e para a segunda, que permitia o uso da filmagem de professores por parte de estudantes nas dependências das escolas. Dos nove parlamentares que compunham a sessão, apenas Priscila e Jorge deram voto contrário ao projeto.

Derrotados na referida comissão, a dupla de vereadores iniciou uma campanha difamatória do projeto, do vereador e do sindicato de professores, fazendo circular a ideia de que o projeto tinha como objetivo ensinar "ideologia de gênero"14 para as crianças, o que os levou a mobilizar todos os elementos presentes nas diversas campanhas de desinformação que se fizera no país quando o "pânico moral"15 em torno da questão foi reproduzido por ocasião das votações dos planos de educação.

Uma imagem, postada por Priscila em seu Instagram, acionava alguns dispositivos enunciativos dignos de nota. A começar pela chamada, em vermelho (cor pela qual a esquerda, e o PT sobretudo, são identificados), alertando para um "perigo" que cercava as crianças: a "permissão para ideologia de gênero nas escolas", para a qual somente ela e Jorge votaram contra. O alerta, assim, produzia a represen-

13 Como se pode perceber, o projeto dialogava, antagonicamente, com os elementos de perseguição docente que compunham o Projeto Escola Sem Partido, do qual os dois vereadores, por razões ideológicas, mostravam-se simpatizantes.

14 Um balanço interessante acerca das campanhas religiosas contra o dispositivo "ideologia de gênero", bem como a proposta de uma arqueologia do termo, pode ser encontrado em Silva (2019a).

15 Ver a definição do termo e seus usos no contexto das referidas votações em Borges e Borges (2018). 
tação dos dois vereadores que se postavam tanto como "denunciantes" do perigo quanto como "defensores" das crianças; e, ainda mais, ao utilizarem a hashtag \#ditaduradegêneonão, ainda se postavam como "democratas".

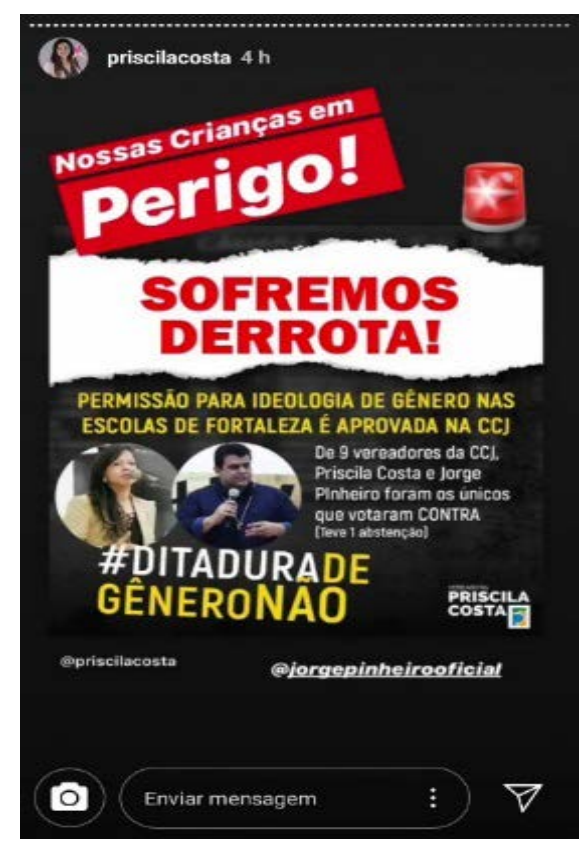

Imagem 1. Mobilização para a votação. Fonte: Instagram de Priscila Costa.

Em vez de usar o termo "revolta", que posicionaria o discurso da vereadora dentro da dimensão cidadã (que, diante do fato, expressaria seu desacordo dentro de uma lógica racional, até mesmo fiel ao movimento legislativo de tramitação de um projeto de lei), a escolha se deu pelo termo "medo", produzindo a ideia de um pânico/caos com o qual ela, e seus seguidores, relacionar-se-iam por meio de sentimentos. Este é um elemento presente na construção de discursos políticos, como nos lembra Charaudeau (2016, p. 89):

No espaço do debate político, como o que está em jogo é uma questão de persuasão e de sedução, não é de espantar que se apela para os sentimentos e que se procure tocar a sensibilidade do auditório. A força dos argumentos empregados depende mais de sua carga emocional do que de seu rigor lógico.

Num segundo momento, incorporando o ethos da representação cidadã, e vocalizando não mais a sua revolta, mas a de outros sujeitos, Priscila compartilha a publicação de uma mulher, a partir da sua publicação, denunciando a "covardia" daqueles que buscavam destruir a "inocência das crianças". De denunciante a 
vereador se tornava representante, canal da voz, meio pelo qual a indignação cidadã se expressava.

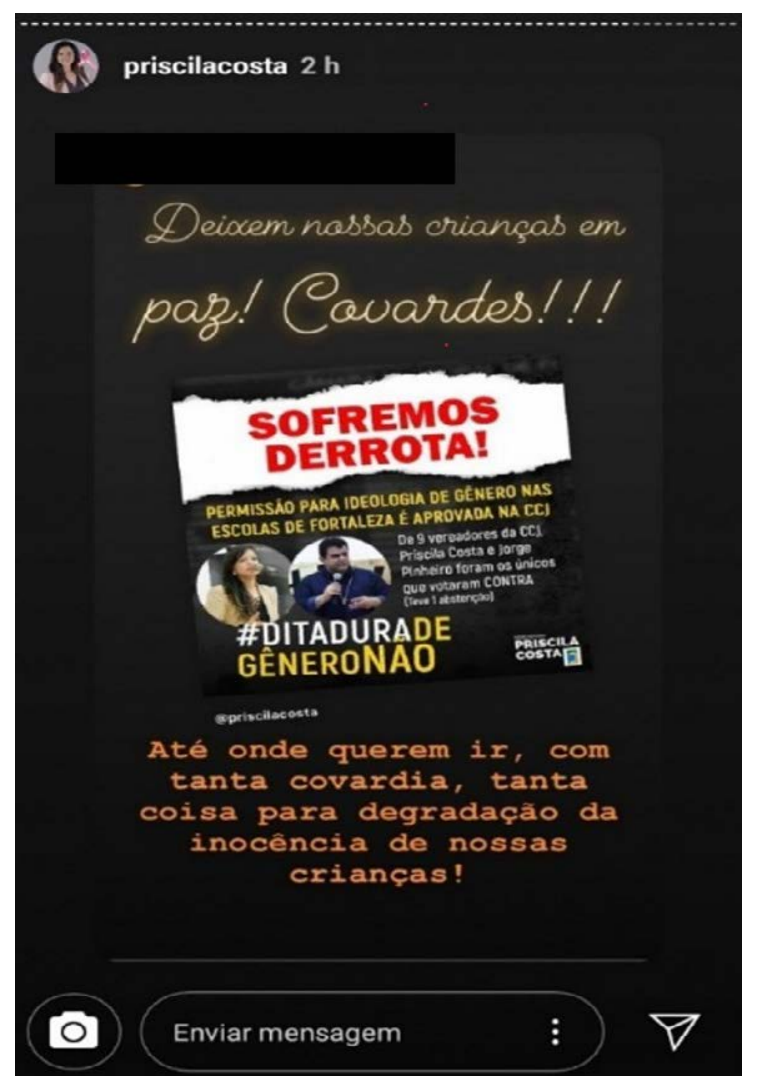

Imagem 2. Repercussão nas redes. Fonte: Instagram de Priscila Costa.

Pelos estudos da comunicação política, compreendemos como tal identificação com o discurso da vereadora, logo tornado compartilhado e reproduzido como sendo seu, é possível por que

[...] o ator político se manifesta na cena do teatro social, com uma dupla identidade, que destina ao outro, seu público, a feição ideal de um cidadão que seria seu duplo, seu cúmplice. [...] é na identidade social do sujeito político que se projeta sua legitimidade [...] A legitimidade social é importante porque é a que dá a toda instância de palavra uma autoridade do dizer (CHARAUDEAU, 2008b, p. 65).

Assim, quando falou que "nossas crianças encontram-se em perigo" (leia-se "nossos filhos"), a vereadora atuou para legitimar-se como aquela que protege as crianças, sendo estas sobretudo as "mães", o que nos permite compreender como aquela que compartilha sua postagem também o faz nessa condição: "deixem 
nossas crianças em paz" (de novo, "nossos filhos”). Nesse sentido, parece-nos que a vereadora seguiu os passos da encenação do drama político, tal como definido por Charaudeau (2016) a descrição da desordem social - o perigo que as crianças corriam -, buscando produzir o feito da angústia ("deixem nossas crianças); a descrição da causa dessa desordem - a existência do projeto de lei, que instalaria a "ditadura de gênero", engendrando a produção de "bodes expiatórios" - não somente o autor do projeto ${ }^{16}$, mas, no caso da imagem, todos os outros membros da CCJ que não acompanharam os dois vereadores no voto contrário; e o apontamento da reparação do mal existente, que se daria com a derrota do projeto.

Após a votação na Comissão, Priscila fez um discurso na tribuna, horas depois postado em suas redes sociais com o título: "Imposição de ideologia de gênero é censura de liberdades". Seguia-se ao título a seguinte mensagem: "Longa batalha e derrota na CCJ. Em Fortaleza, foi aprovada na Comissão, a permissão para o ensino da Ideologia de Gênero nas Escolas. Depois de ouvir a bancada do PT afirmar que Ideologia de Gênero não tem relação com Liberdade de Consciência. Vereadora Larissa Gaspar explica para todos, o caráter ditatorial da tal ideologia"17.

Comecemos pelo título: um total desvirtuamento do projeto, que não versava sobre ensino de qualquer temática em particular, muito menos do que nomeou como "ideologia de gênero"; o texto original não indicava "censura" alguma, mas exatamente a "liberdade de cátedra", que, agora, segundo a vereadora, estaria ameaçada pela "ideologia de gênero", que foi incorporada ao texto original por meio da emenda de Jorge Pinheiro, ainda que em teor negativo, pela "proibição" de seu "ensino". Por isso, no momento em que sua emenda foi derrotada, iniciou-se a campanha difamatória ${ }^{18}$ de dizer que o projeto visava ensinar aquilo que não se proibia.

Priscila não se dirigia ao autor do projeto, Evaldo Lima, mas à vereadora Larissa Gaspar (PT), num movimento que lhe permitia antagonizar na questão do gênero, assim como no seu discurso antagoniza com outro vereador do PT, Guilherme Sampaio, a quem a vereadora se opunha por este defender, segundo ela, uma ideologia que "imposta pela força do Estado, tem tudo a ver com ferir a crença das famílias brasileiras”. A argumentação, servindo para ratificar a

16 Que, é importante dizer, em nenhum momento foi alvo das mobilizações dos grupos conservadores ou dos dois parlamentares, deslocando para o sindicato dos professores ou para o PT as acusações.

17 Disponível em: https://www.instagram.com/priscilacosta/?hl=pt-br.

18 A partir disso podemos compreender melhor a afirmação de Charaudeau, segundo a qual "a palavra política não é, de modo algum, uma injunção, mas uma sutil sugestão para fazer, para pensar, e, mais cinicamente, para se deixar pensar [...] (2006, p. 89). 
representação do partido como "inimigo da fé cristã”, equaciona PT-ideologia de gênero-destruição das famílias ${ }^{19}$. Ao mesmo tempo, se desqualificam as ideias do opositor, mostrando-as como portadoras de consequências nefastas ("ferir a crença das famílias") e representando-o como inimigo.

No mesmo dia, em suas redes sociais, a vereadora anunciava uma live a ser realizada às 22hs, com uma mãe, live essa intitulada "pais contra ideologia de gênero nas escolas". Na descrição da live podia se ler: "mãe que testemunhou ato de sindicato na escola, quebra o silêncio! Hoje, com material que sindicato entregou nas escolas assumindo lutar pelo ensino da Ideologia de gênero nas escolas, estaremos falando com todos os pais de Fortaleza! Podem nos chamar de fake news! Somos mães e não vamos parar!"20.

Na verdade, o material distribuído pelo sindicato em nenhum momento trata de "ensino" de gênero; o comentário sobre o material, por parte dela e de Jorge, consistia em mais um mecanismo de deturpação do texto para os objetivos por eles traçados: confundir a opinião pública e mobilizar suas bases contra a aprovação do projeto $^{21}$. Veja, na imagem abaixo, o que constava no documento era um conjunto de bandeiras, dentre as quais havia a de "liberdade de orientação de gênero", mas não se diz que tal liberdade consistia em uma pauta para sala de aula. Era uma luta mais ampla, de convivência social, de direito social, que incluía, também, a liberdade religiosa.

19 Na manipulação da representação política como identidade pautada nos valores, a questão da "família" atua como importante componente a ser mobilizado, sobretudo no campo político da direita. Sobre isso, importa saber que "o valor família, da sociedade familiar, pois é em seu seio que se fabrica o indivíduo. No pensamento de direita, não é o indivíduo que fabrica o grupo, mas o grupo que fabrica o indivíduo, daí a importância da filiação, do inato e do peso da tradição familiar que essencializa o grupo e o indivíduo num destino imutável” (CHARAUDEAU, 2016, p. 99-100).

20 Disponível em: https://www.instagram.com/priscilacosta/?hl=pt-br.

21 Sem dúvida alguma, umas das problemáticas que as transformações operadas no campo midiático, sobretudo com o aparecimento das redes sociais, é a questão da "regulação do discurso político". Se, para Charaudeau (2008b, p. 28) a mídia constituía-se como um dos mecanismos de produção e aferição do dito político, a "liberdade" proporcionada pelas redes sociais faz com que os sujeitos falem a uma coletividade (seus seguidores) que lhes desobriga a submeter-se ao escrutínio da prova, transformando-se cada vez mais em um conjunto de seguidores que se relacionam aos moldes de uma tribo. Na rede do político não há espaço para o contraditório, não se forma uma arena pública de discussão, o que inviabiliza o confronto com o dissenso e, mesmo, a necessidade da prova. A crença no dito pelo homem político, aqui, ao que me parece, se multiplica numa potência assustadora. 


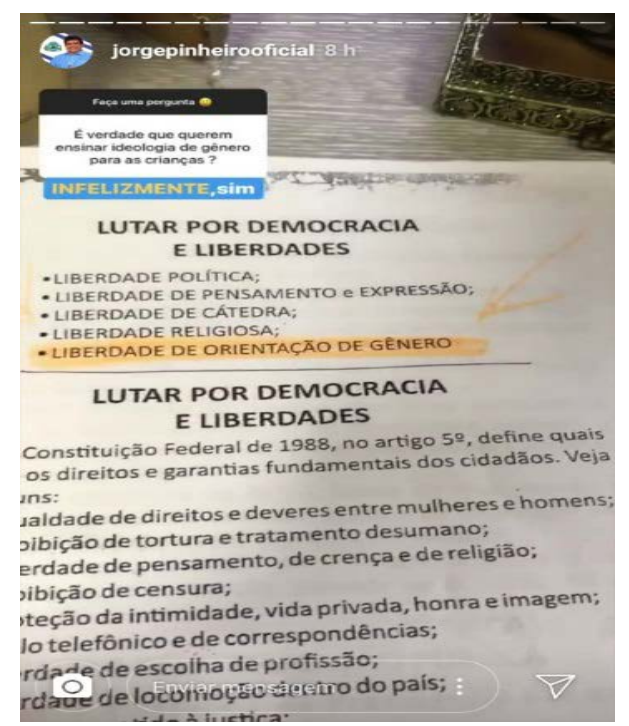

Imagem 3. Pautas do Sindicato. Fonte: Instagram de Jorge Pinheiro.

Para reforçar ainda mais o espírito de objeção ao projeto e ao sindicato, o vereador carismático compartilhou a página do material do sindicato em suas redes abaixo de imagens religiosas, com destaque para a do Arcanjo São Miguel, que na mitologia católica é crido como aquele que derrotou o demônio ${ }^{22}$. Respondendo a uma pergunta de um seguidor, se era verdade que queriam "ensinar ideologia de gênero nas escolas", o vereador responde positivamente, mas sem mostrar onde, no texto do projeto, isso estava dito, recorrendo, por sua vez, ao material do sindicato que, mesmo não dizendo o que sua postagem dizia, servia como prova semântica para seus objetivos.

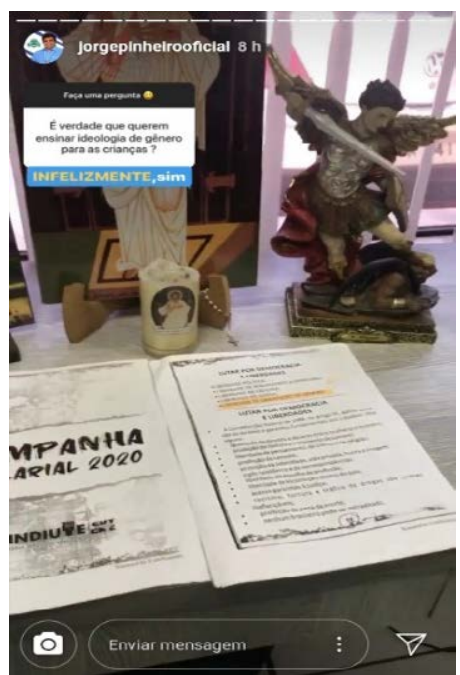

Imagem 4. Pautas como mal a ser vencido. Fonte: Instagram de Jorge Pinheiro.

22 A presença da semântica em torno do "demônio" em meio aos pentecostais, universo com o qual a RCC comunga das ideias, é analisado em Mariano (2014). 
Estava claro o que devia ser feito: se aos dois vereadores cabia fazer oposição na Câmara, aos seus seguidores cabia a oração. Estava firmado o pacto político-religioso: confiem em nós, estamos trabalhando pela derrota do projeto! Confiem e orem! É o que é dito, em outras palavras, pelo vereador:

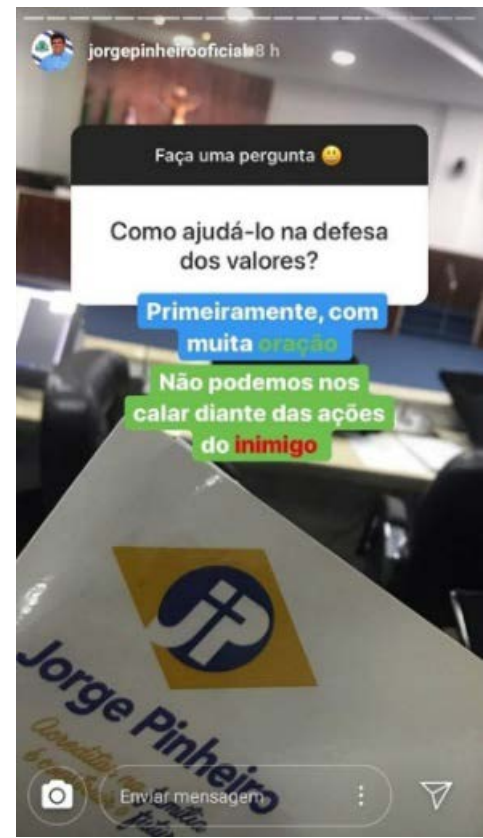

Imagem 5. Mobilização das redes. Fonte: Instagram de Jorge Pinheiro.

Antes de tudo, seria preciso "muita oração". A representação ali esboçada/pactuada é de origem transcendental: o eleitor deve, antes de tudo, orar. Destaque-se, também, o uso do termo "inimigo", em vermelho: além de referir-se implicitamente ao PT, cuja cor é o vermelho, o termo diz respeito, na cosmologia cristão, ao próprio demônio. Logo, o que o vereador estava a chamar de "ações do inimigo", para seus seguidores era, na verdade, as ações da esquerda, do sindicato, do PT; era o projeto propriamente dito. Logo, ao demônio se vence com "oração".

A ideia de desordem, destruição, caos, que produzem ao mesmo tempo a persona de um inimigo a se derrotar, é um dos elementos constituintes do discurso político, universo sobremaneira eivado de elementos afetivos e valorativos:

O discurso político, que procura obter a adesão a um projeto ou a uma ação, ou a dissuadi-lo de seguir o projeto adverso, insiste mais particularmente na desordem social da qual o cidadão é vítima, na origem do mal que se encarna em um adversário ou um inimigo, e na solução salvadora encarnada pelo político que sustenta o discurso (CharaUdeau, 2008b, p. 91). 
Aqui, a desordem é a destruição das famílias, originada na suposta lei que autorizaria o ensino de "ideologia de gênero", cuja solução salvadora era tão somente a rejeição do projeto de lei. Em uma outra passagem, o autor nos fala da "dramatização do discurso político", que nos parece auxiliar, também, na compreensão das imagens acima anexadas, uma vez que envolvem um conjunto de símbolos mobilizados para fomentar a repulsa ao projeto que tramitava:

É à medida que as emoções correspondem a representações sociais, constituídas por uma mistura de julgamentos, de opiniões e de apreciações, que elas podem desencadear sensações ou comportamentos, que elas podem ser utilizadas para tentar seduzir, ameaçar, aterrorizar, enfim, atrair um interlocutor ou um auditório (Charaudeau, 2008b, p. 89).

O projeto foi à votação no dia 31 de outubro, depois de uma acirrada campanha de desvirtuamento por meio das redes sociais. Durante a sessão, que contou com a presença de membros do sindicato dos professores, de um lado, e de militantes de movimentos conservadores, sobretudo o "endireita Fortaleza", apresentados como "pais e mães", debates acalorados. Coube ao autor do projeto, frente à intensa campanha de desgaste que sofrera, retirar o projeto de pauta.

Reforçando a imagem do pacto político-religioso, Jorge posta-se no plenário, e nas redes, com o terço (objeto católico de devoção mariana) na mão, reproduzindo a encenação de uma batalha espiritual em curso naquele espaço, mostrando-se "preparado" para o momento pelas orações de seus seguidores-eleitores, aos quais havia pedido, como vimos anteriormente, "muita oração". A imagem opera ao mesmo tempo: a legitimação do vereador como agente do campo religioso e do campo político; a deslegitimação do projeto e da esquerda (novamente, a cor em vermelho); e a prestação de contas ao seu eleitor (se pedira oração, agora era o momento de ele mesmo mostrar-se como "homem de oração"). 


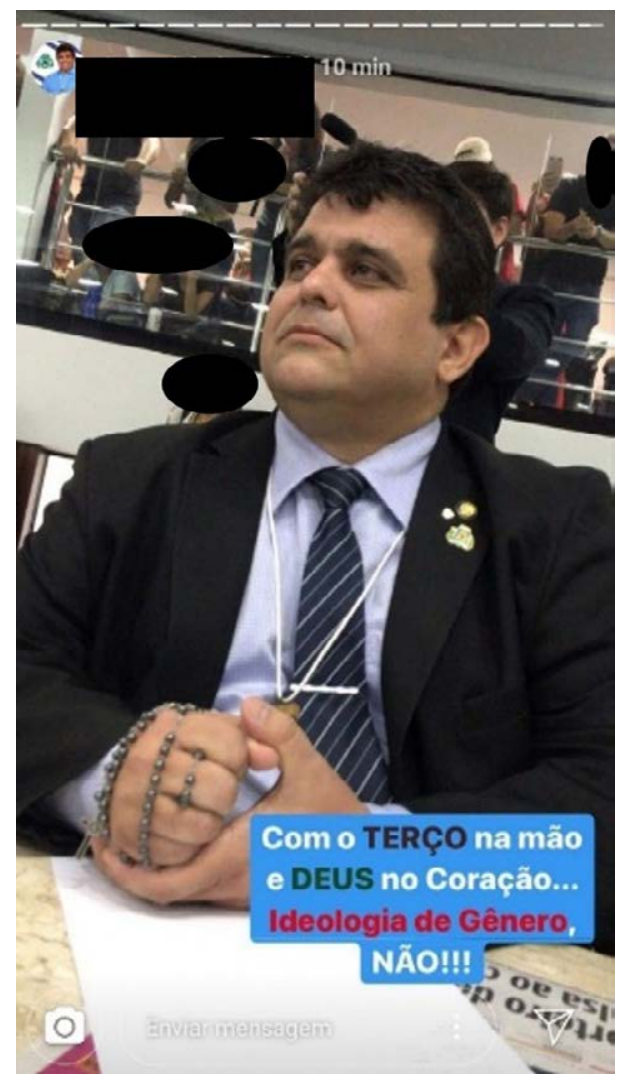

Imagem 6. Momento do debate do Projeto. Fonte: Instagram de Jorge Pinheiro

Essa imagem ${ }^{23}$ compartilhada pelo vereador nos pareceu como a de maior significado político, atuando como um selo do pacto político-religioso dele com seus seguidores. A escolha de cada detalhe da imagem (o terço na mão, o cordão que o identifica como membro da comunidade, o olhar confiante e os termos em destaque - Deus, terço e ideologia de gênero) atuam para aproximá-lo de valores socialmente compartilhados. Como lembra Charaudeau (2008b, p.87):

No domínio político, a construção das imagens só tem razão de ser se for voltada para o público, pois elas devem funcionar como suporte de identificação, via valores comuns desejados. O ethos político deve, portanto, mergulhar nos imaginários populares mais amplamente partilhados, uma vez que deve atingir o maior número, em nome de uma espécie de contrato de reconhecimento implícito. O ethos é um espelho no qual se refletem os desejos uns dos outros.

23 "É, afinal, a imagem que o locutor constrói, deliberadamente ou não, em seu discurso, que constitui um componente da força ilocutória” (Amossy, 2018, p. 89). 
Vejamos a cobertura realizada por um veículo de imprensa:

\section{Câmara de Fortaleza retira projeto de liberdade de ensino após tumulto entre professores e religiosos}

Líderes religiosos e bancada conservadora alega que liberdade de cátedra permite que professores ensinem 'ideologia de gênero'.

Um projeto que trata da liberdade de ensino dos professores de Fortaleza foi retirado da pauta de votação na Câmara Municipal nesta quinta-feira (31), após tumulto e confusão entre manifestantes. Desde o começo da sessão legislativa, dezenas de professores ocuparam as galerias da Câmara e o pátio externo do prédio para pressionar pela aprovação do projeto. Lideranças religiosas e integrantes de movimentos de direita em Fortaleza também compareceram.

A proposta que trata da liberdade de cátedra e de expressão dos professores tem gerado reações contrárias da bancada conservadora e acusações, em discursos de vereadores no Plenário e nas redes sociais, de que o projeto visa permitir aos docentes o ensino do que chamam de "ideologia de gênero". Nos bastidores, já se previa que a matéria seria rejeitada, inclusive com abstenções.

Projeto 'contaminado'

O autor do projeto, vereador Evaldo Lima (PCdoB), ao perceber a força da articulação da bancada religiosa, pediu a retirada da proposta da pauta de votação em acordo com os professores.

“O projeto acabou sendo contaminado por uma perspectiva equivocada de que tratava de pauta de costumes. Em nenhum momento, o projeto que trata de liberdade de cátedra trata da liberdade de costumes", disse Evaldo Lima.

Houve tumulto e bate-boca quando professores tentaram ocupar o Plenário para pressionar pela aprovação da retirada de pauta. A Guarda Municipal interveio e bloqueou o acesso dos manifestantes. Em votação simbólica, o projeto foi retirado da pauta de votação.

A bancada religiosa comemorou o resultado. "Vitória nossa. Enquanto indivíduo, o professor tem liberdade de expressão, claro, mas (o projeto) está dizendo que, dentro de sala de aula, o professor não tem nenhuma sequência de plano pedagógico para seguir? É dizer o que quer na hora que quer? A gente defende a liberdade de cátedra, que é o ensino da matéria”, disse a vereador Priscila Costa (PRTB) (Disponível em: https://g1.globo.com/ce/ceara/noticia/2019/10/31/ camara-de-fortaleza-retira-projeto-de-liberdade-de-ensino-apos-tumulto-entre-professores-e-religiosos.ghtml. Acesso em 10 de maio de 2020). 
Embora a reportagem não diga, mas importa ressaltar que o acesso de professores ao plenário foi barrado, ao passo que se observou um grupo de pastores e líderes religiosos deslocando-se por dentro do plenário, com acesso direto aos vereadores. Outro veículo assim noticiou:

Projeto sobre liberdade de cátedra sai da pauta da Câmara após confusão e articulação de religiosos

O projeto que trata sobre liberdade de cátedra dos professores da rede municipal de Fortaleza foi retirado da pauta de votação da Câmara Municipal após tumulto e articulação da bancada religiosa nesta quinta-feira (31).

O autor do projeto, vereador Evaldo Lima (PCdoB), foi quem solicitou a retirada, em acordo com os professores, após perceber a força da articulação da ala conservadora na Casa. Nos bastidores, já se previa a rejeição à proposta durante a votação no Plenário, inclusive com abstenções.

Em votação simbólica, a proposta foi retirada da pauta no final da manhã. “O projeto acabou sendo contaminado por uma perspectiva equivocada de que tratava de pauta de costumes. Em nenhum momento, o projeto que trata de liberdade de cátedra trata da liberdade de costumes”, disse Evaldo Lima.

A bancada religiosa comemorou o resultado. "Vitória nossa. Enquanto individuo, o professor tem liberdade de expressão, claro, mas (o projeto) está dizendo que, dentro de sala de aula, o professor não tem nenhuma sequência de plano pedagógico para seguir? É dizer o que quer na hora que quer? A gente defende a liberdade de cátedra, que é o ensino da matéria”, disse a vereador Priscila Costa (PRTB).

\section{Manifestantes}

Desde o começo da sessão, dezenas de professores ocuparam as galerias da Câmara e o pátio externo do prédio para pressionar pela aprovação do projeto. Lideranças religiosas e integrantes de movimentos de direita em Fortaleza também compareceram.

Houve tumulto quando professores tentaram ocupar o Plenário para pressionar pela aprovação da retirada de pauta. A Guarda Municipal interferiu e bloqueou o acesso dos manifestantes.

O Projeto de Lei Ordinária ( $\left.\mathrm{N}^{\circ} 524\right)$ diz que a medida "dispõe sobre a liberdade de expressão no ambiente escolar e a proteção do professor frente a casos de violência contra o mesmo, no exercício da sua atividade profissional".

Desde o início da tramitação, a proposta tem gerado reações contrárias da bancada conservadora e acusações, em discursos de vereadores no Plenário e nas 
redes sociais, de que o projeto visa permitir aos docentes o ensino do que chamam de "ideologia de gênero" 24 .

Nas redes sociais, a encenação da vitória pela retirada do projeto pode ser observada na imagem a seguir, produzindo a encenação da comemoração da vitória como algo a ser compreendida, por seus seguidores, no plano espiritual:

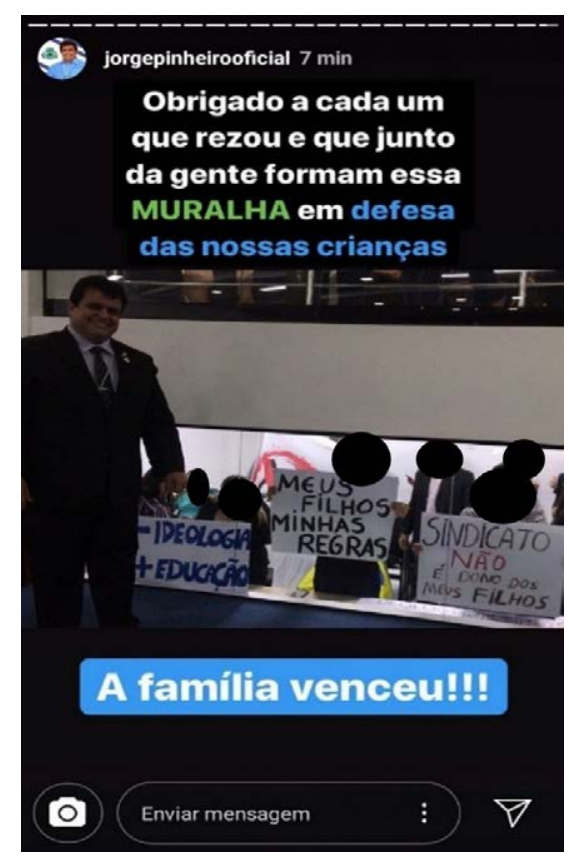

Imagem 7. Comemoração com os apoiadores. Fonte: Instagram de Jorge Pinheiro.

A imagem da muralha evidencia uma concepção defensiva e agressiva de religião, evocando a tutela das crianças. Todavia, se os vemos alertas no campo moral, não os vemos com idêntico entusiasmo militando contra o trabalho ilegal infantil, por exemplo.

\section{4 - CONSIDERAÇÕES FINAIS: QUAL O LUGAR DO DISSENSO NO DISCURSO POLÍTICO- RELIGIOSO?}

Para apresentar um desfecho a este artigo, mas não para a discussão engendrada, escolhemos o seguinte caminho: considerar o lugar do dissenso no espaço político representativo quando este torna-se lócus de exercício de poder de sujeitos que se creem representantes de crenças religiosas. que devem ser impostas ao

24 Disponível em: https://diariodonordeste.verdesmares.com.br/editorias/politica/online/ projeto-sobre-liberdade-de-catedra-sai-da-pauta-da-camara-apos-confusao-e-articulacao-de-religiosos-1.2168729. Acesso em 11 de maio de 2020 
conjunto da sociedade. O dissenso torna-se um fosso, pois os vereadores produziram dois efeitos com sua atuação religiosa fundamentalista: a autolegitimação como representantes fiéis da cosmovisão cristã e a nomeação do autor do projeto e da esquerda em geral, como "inimigos da fé em Cristo" e, portanto, da nação brasileira que seria toda cristã e do povo cearense, a caminho da hegemonia cristã, ou de um certo tipo de cristianismo excludente e reacionário.

A partir de elementos próprios de sua fé, pretende-se guerrear contra propostas de atores do campo político liberais, centro e esquerda, laicos ou não, classificando-os como "contrárias à fé", "contrárias ao povo", "contrárias à maioria” e, portanto, "contrárias à democracia”, entendida como "governo da maioria”, maioria esta que, no caso de Fortaleza, é cristã.

Para ilustrar essa discussão que encerra, pesarosamente, este artigo com a visualização da imagem abaixo, que registra o momento imediatamente após a retirada do projeto de lei. Ela nos mostra Priscila e Jorge em oração, no espaço da Câmara, tocados por um pastor, liderança religiosa cristã. A retirada de pauta do projeto, movimento cotidiano das casas legislativas, é comemorada como um feito de “oração", vitória, portanto, de uma divindade, não do movimento político próprio aos legisladores.

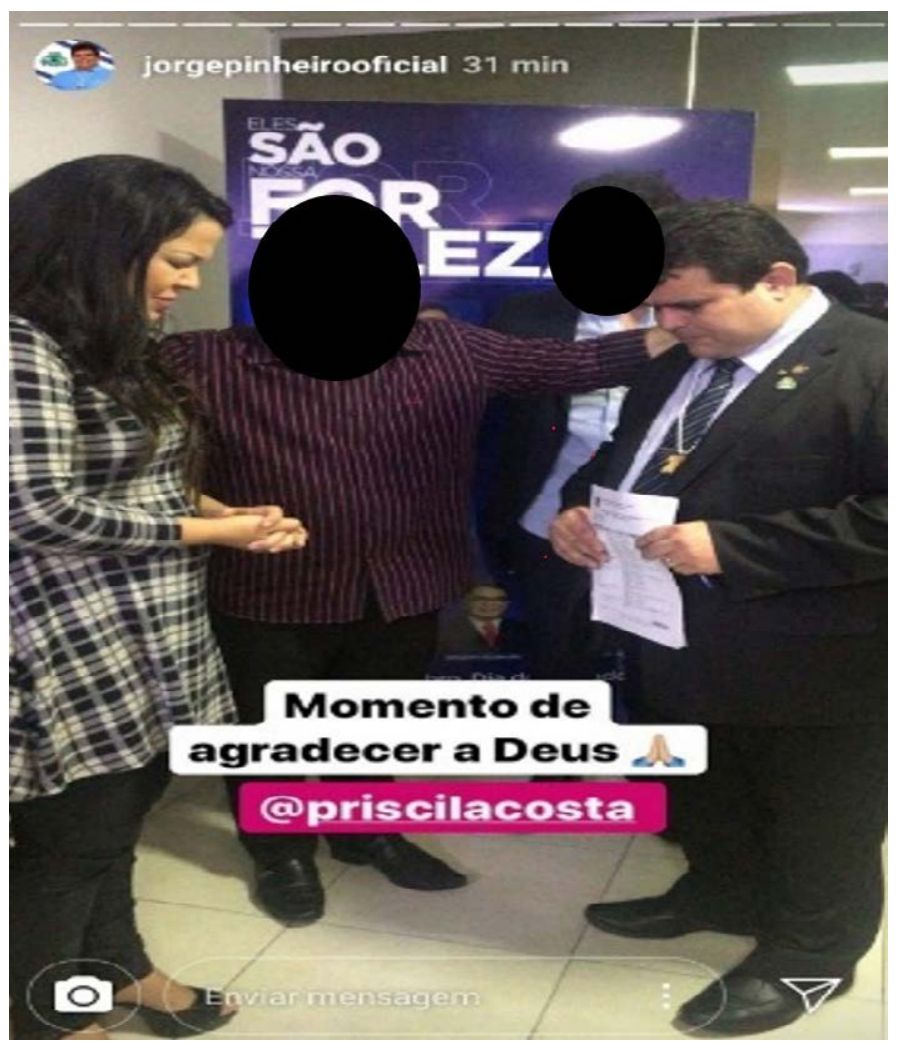

Imagem 8. Oração pós-vitória. Fonte: Instagram de Jorge Pinheiro. 
Pergunta-se qual a possibilidade de se opor a uma ação que seja interpretada como mandada por deus ou produzida por uma oração? Como organizar um consenso em torno de uma política/lei que porte dissenso quando parte deste é produzida pela compreensão de alguns dos atores do campo que o semantizam como contra a sua fé? Que enunciados são possíveis a partir daí?

Em recente reflexão, Amossy (2017) defende a ideia de que o dissenso, cuja manifestação contemporânea por excelência se dá por meio do instrumento da polêmica no espaço público, é constituinte dos regimes democráticos, uma vez que estes atuam não por meio da eliminação das dissensões, mas por meio da sua gestão. Gerir os desacordos, não os impedir, é o que caracterizaria as democracias. Na medida em que as convicções contemporâneas se agudizam, mas os dissensos passam a jogar papel importante no universo político.

Para essa autora, os dissensos devem ter lugar nas democracias porque é por meio deles que se constituem espaços públicos de discussão efetivos, com segmentos da vida social se constituindo em suas particularidades para o embate público, na defesa de seus valores e ideais, auxiliando, por meio desse confronto, no próprio exercido democrático da discussão. Todavia, nos limites tensionados da democracia liberal representativa, a máquina de guerra religioso-política, demonstrada nos dois vereadores entendidos como tipo ideal, protótipo dos políticos religiosos cristãos conservadores-reacionários, acelera o desgaste do tecido da racionalidade política.

Como resultado das questões postas e da metodologia qualitativa, nosso artigo assinala que a entrada massiva da máquina de guerra reacionária-conservadora-cristã, pautada pelo espetáculo, teatro e metafísica da negação do outro, produz um espaço público menos plural, menos acolhedor de dissensos e discursos discordantes e mais inflamado por guerras entre "inimigos", os quais, ou se submetem, ou são eliminados.

\section{REFERÊNCIAS}

Amossy, Ruth. A argumentação no discurso. São Paulo: Contexto, 2018.

Amossy, Ruth. Apologia da polêmica. São Paulo: Contexto, 2017.

BERGER, Peter; ZiJDERVELD, Anton. Em favor da dúvida: como ter convicções sem se tornar um fanático. Rio de Janeiro: Elsevier, 2012.

Borges, Rafaela Oliveira; Borges, Zulmira. Pânico moral e ideologia de gênero articulados na supressão de diretrizes sobre questões de gênero e sexualidade nas escolas. Rev. Bras. Educ. vol.23, Rio de Janeiro, 2018.

Bourdieu, Pierre. O campo político. Rev. Bras. Ciênc. Polít, no.5, Brasília Jan./Jul 2011. 
Bourdieu, Pierre. O poder simbólico. 16.ed. Rio de Janeiro: Bertrand Brasil, 2012.

Burity, Joanildo. A cena da Religião Pública: contingência dispersão e dinâmica relacional. Novos Estudos CEBRAP, São Paulo, n.102, São Paulo, p. 89-105, jul-2015. Disponível em <https://www.academia.edu/22433913/A_CENA_DA_ RELIGI\%C3\%83O_P\%C3\%9ABLICA>. Acesso em: o1 abr.2018.

CAmpos, Leonildo Silveira. O projeto político de "governo do justo": os recuos e avanços dos evangélicos nas eleições de 2006 e 2010 para a Câmara Federal. Debates do NER, ano II, n.18, pp. 39-82, jul/dez., Porto Alegre, 2010.

Charaudeau, Patrick. A conquista da opinião pública - como o discurso manipula as escolhas políticas. São Paulo: Contexto, 2016.

Charaudeau, Patrick. Discurso Político. São Paulo: Contexto, 2008b.

Charaudeau, Patrick. Linguagem e discurso: modos de organização. São Paulo: Contexto, 2008a.

Cunha, Magali. “'É preciso salvar a família’: gênero, religião e política no contexto do neoconservadorismo evangélico nas mídias no Brasil”. In: Cunha, Magali; Lopes, Paulo Victor Leite; Luı, Janayna (orgs.) Religião e política: medos sociais, extremismo religioso e as eleições 2014. Rio de Janeiro: Instituto de Estudos da Religião, 2017.

DIP, Andrea. Em nome de quem? A bancada evangélica e seu projeto de poder. Rio de janeiro: Civilização Brasileira, 2018.

FReITAS, Marcelo Silva de. (Des) contentamento com a política e representação: o exercício parlamentar dos vereadores religiosos na câmara de fortaleza. 2020. Orientador: Emanuel Freitas da Silva. 184f. Dissertação. Programa de Pós-Graduação em Políticas Públicas. Universidade Estadual do Ceará, Fortaleza, 2020.

Machado, Maria das Dores. Aborto e ativismo religioso nas eleições de 2010. Revista Brasileira de Ciência Política, n.7, p.25-37, jan.-abr. 2012. Disponível em: <http:// www.scielo.br/pdf/rbcpol/n7/ao3n7.pdf >. Acesso em: 24 fev.2018.

MACHADO, Maria das Dores. Pesquisa com líderes religiosos: questões éticas e metodológicas. Estudos Sociológicos, Araraquara, v.18, n.34, p.39-56, jan-jun. 2013. Disponível em: < https://periodicos.fclar.unesp.br/estudos/article/view/5972/4525>. Acesso em: 27 fev.2018.

Machado, Maria das Dores. Política e religião. Rio de Janeiro: FGV, 2006.

MACHADO, Maria das Dores. Religião e política no Brasil contemporâneo: uma análise dos pentecostais e carismáticos católicos. Religião e Sociedade, Rio de Janeiro, vol.35, p.45-72, dez-2015. Disponível em: < http://www.scielo.br/pdf/rs/v35n2/o10o8587-rs-35-2-00045.pdf >. Acesso em: 30 mar.2018. 
Machado, Maria das Dores. Religião, cultura e política. Religião e Sociedade, Rio de Janeiro, n.32, vol. 2, p. 29-56, 2012. Disponível em: <http://www.scielo.br/pdf/rs/ v32n2/o3.pdf >. Acesso em: 12 fev.2018.

Mariano, Ricardo. Neopentecostais - sociologia do novo pentecostalismo no Brasil. 5.ed. Rio de Janeiro: Edições Loyola, 2014.

MarIz, Cecilia. “Catolicismo no Brasil contemporâneo: reavivamento e diversidade”. In: Teixeira, Faustino. As religiões no Brasil. Petropólis, RJ: Vozes, 2006.

Miranda, Julia. Carisma, sociedade e política: novas linguagens o religioso no político. Rio de Janeiro: Jorge Zahar, 1999.

Miranda, Julia. Católicos carismáticos e as eleições municipais de 2012. Ciências Sociais Unisinos, São Leopoldo, n. 51, vol. 2, p. 201-211, mai-ago 2015. Disponível em:<http://revistas.unisinos.br/index.php/ciencias_sociais/article/viewFile/ csu.2015.51.2.10/4794>. Acesso em: 23 fev.2018.

Silva, Emanuel Freitas da. "Em nome da natureza": discursos e mobilizações católicas no Brasil em torno do gênero na escola. Religare: Revista do Programa de Pós-Graduação em Ciências das Religiões da UFPB, v. 15, n. 2, p. 505-525, 20 jan. 2019.

Silva, Emanuel Freitas da. Cenas públicas de enfrentamento político-religioso: apontamentos de tensões entre parlamentares evangélicos e o governo de Dilma Rousseff. Faces de Clio, v.5, n.9, pp. 146-161, 2019.

Silveira, Emerson José Sena da. Corpo, emoção e rito: antropologia dos carismáticos católicos. Porto Alegre: Armazém Digital: 2008. Disponível em: https://www. academia.edu/43280633/Corpo_emo\%C3\%A7\%C3\%A30_e_rito_antropologia_dos_ carism\%C3\%A1ticos_cat\%C3\%B3licos_livro_completo_Acesso em: 16 jun 2020.

Silveira, Emerson José Sena da. Terços, "santinhos” e versículos: A relação entre católicos carismáticos e a política. Rever - Revista de Estudos da Religião, São Paulo, PUC-SP, ano 8, p.54-74, mar. 2008. Disponível em: https://www.pucsp.br/rever/rv1_2008/t_ silveira.pdf Acesso em: 16 jun 2020.

TADVALD, Marcelo. Eleitos de deus e pelo povo: os evangélicos e as eleições federais de 2010. Debates do NER, ano II, n.18, pp. 83-109, jul/dez., Porto Alegre, 2010. 